\title{
STRATEGIES AND TACTICS OF COMMUNICATIVE SABOTAGE AND LINGUAL MEANS OF THEIR REPRESENTATION IN POLITICAL DISCOURSE
}

\section{Nelia Pavlyk ${ }^{1}$ \\ Hanna Vusyk ${ }^{2}$}

DOI: https://doi.org/10.30525/978-9934-26-050-6-59

Analysis of scientific and theoretical sources on the research topic suggests that many scientific papers are devoted to the issues of strategic speech influence, but the problem of strategies and tactics of communicative sabotage is insufficiently studied, in particular in domestic sociolinguistics.

The purpose of the study is to describe the strategies of communicative sabotage and to organize various ways and means of its representation in the

\footnotetext{
${ }^{1}$ Berdiansk State Pedagogical University, Ukraine

${ }^{2}$ Berdiansk State Pedagogical University, Ukraine
} 
Ukrainian-speaking space. The development of the raised problems will be facilitated by the following tasks: 1) to characterize sabotage as a phenomenon of communication; 2) to analyze the reasons for the use of communicative sabotage; 3) to identify the components of communicative sabotage; 4) to identify verbal means of expressing communicative sabotage on the example of a political interview.

In the course of the research a set of methods of scientific research was used, in particular: interpretive and analytical method, on the basis of which Ukrainian and foreign sources were studied with the use of synthesis, analysis, systematization, etc.; the method of theoretical generalization, which contributed to the formulation of conclusions; sociological method involved in the study of the problems of communication strategies and tactics; contextual and interpretive method used to describe the means of communicative sabotage expression.

The term «sabotage» does not belong to the linguistic ones, it is used in the context of socio-political struggle in the sense of covert counteraction, violent protest, forms of economic struggle, failure or refusal to perform tasks, and so on. In the «Great Explanatory Dictionary of the Modern Ukrainian Language» sabotage is explained as 1) deliberate disruption of work, which is manifested in the direct rejection of it or careless, dishonest performance; 2) covert opposition to the implementation of something [3, p. 1094]. The term «sabotage» occurs in a variety of historical, socio-political contexts, materials on military issues, and at the same time can be used in relation to radical actions, such as violent protest, destruction, subversive activities, and disobedience.

In the examined scientific literature it is communicative sabotage which is considered in the context of speech activity as a method of speech influence in the form of a dialogue, which expresses the latent resistance of the speaker and aims to ignore the content of the statement to avoid communication, to have distortion or concealment of information [2, p. 11]. Scholars compare communicative sabotage with a number of speech and communicative phenomena, in particular, speech aggression, conflict, language resistance, language violence, communication pressure, manipulation, language demagoguery, which led to the conclusion that sabotage, on the one hand, combines these forms of behavior, on the other hand, is not identical to any of them [2, p. 11-12].

During communication, saboteurs use threats, orders, negative criticism, offensive nicknames, concealment of important information, interrogation, praise with subtext, manifestation of motives, untimely advice, refusal to discuss the issue, rivalry, change of topic, etc. [5, p. 36-38]. 
Researchers point to the main reasons for the process of sabotage, namely: a) external - violation of communicative norms and rules of conduct in a particular communication situation; b) internal - a protective reaction (sometimes aggressive) caused by interference in the personal space of the speaker; non-cooperative behavior during communication due to psychoemotional state; focusing on a more significant aspect of the conversation [2, p. 13; 6, p. 9].

Recently, more and more scientists turn to the question of communication strategies and tactics that can be used to influence the interlocutor. Summarizing the various interpretations, we emphasize that the choice of methods and means of these processes, their planning and implementation depend on the specific communicative situation and interpersonal relationships of its participants. Communicative sabotage strategies and tactics help to offer covert resistance during communication.

Sabotage as a communicative strategy within non-cooperative communication is manifested in the use of appropriate speech tactics that generally implement the strategy of provoking a conflict situation. A review of the scientific literature (in particular, the works by V. Andreeva, O. Volkova, etc.) allows us to name the following: reports that contain false information; statements with excessive display of emotion, dissatisfaction, indignation; provocative questions; various manifestations of trolling (offensive, bullying) as a form of communicative behavior in case of unwillingness to continue communication; evasion of the direct answer, change of a subject of conversation, redirection; disregard; silence; outright negative reaction of the saboteur, etc. Such techniques and tactics allow speakers to avoid communication, hide information, manipulate, and influence the interlocutor.

Let's follow the functioning of typical language means of expressing the strategy of sabotage on the example of interviews with Ukrainian authorities, politicians, public figures, etc., published on the websites of domestic newspapers «Den'», «Dzerkalo Tyzhnya», Internet portals «RBC-Ukraine», «NV Business», «Radio Svoboda», «GORDON», etc. Political interview as a speech genre involves a cooperative communication strategy, cooperative behavior, represented by detailed forms of answers to the interlocutor's questions and the use of tolerant ways to avoid communication, to protect own positive image.

Thus, the following verbal means of expressing communicative sabotage were found in the examined text material:

$\rightarrow$ Answer the question in the form of a question.

$\rightarrow$ Change of the topic of conversation, expressed by lexical means.

$\rightarrow$ Negative constructions. 
$\rightarrow$ Emotionally colored or evaluative vocabulary with a negative connotation.

$\rightarrow$ Refusal to communicate like «NO COMMENTS».

$\rightarrow$ Accusation, verbal aggression.

$\rightarrow$ Irony, self-irony, sarcasm.

There were few provocative constructions (using such a type of compounds And What?) or motivational sentences (such as Distance! Don't ask stupid questions!) in the analyzed political interviews, because in political discourse there are mostly correct means to avoid answering or refusing to communicate than more categorical, inherent, for example, to colloquial speech. We agree with the statement of V. Andreeva that verbal means of expression directly depend on the type of discourse in which the method of communicative sabotage was used [1].

The analysis of the text material shows that the participants of communication choose mainly tolerant communicative techniques and linguistic means of representation, which are acceptable in the specified communication situation and do not lead to its complete disorder. Among the communication strategies used in the surveyed political interviews, the avoidance strategy prevails, in particular, the tactics of avoiding a direct answer, changing the topic of conversation, etc., and the strategy of negative reaction, namely: tactics of denial, indignation, and refusal.

It can be concluded that in relation to communicative processes, tactics are considered as a set of techniques and tools aimed at achieving the goal within the chosen strategy, the latter involves the planning of a communicative act. Communicative sabotage is presented as a way of verbal influence on the interlocutor and contains a hidden resistance aimed at ignoring certain statements. The choice and implementation of communication strategy and tactics depend on the specific communication situation, the purpose of communication, social status and attitudes of its participants, as well as the type of discourse.

We see the prospect of research in the need for thorough and comprehensive study by domestic linguists of the problems of communicative sabotage as a phenomenon of dialogic speech, interpersonal interaction, cooperative and non-cooperative communication strategy in different types of discourse. We consider it appropriate to further consider the ways and means of representing strategies of communicative sabotage in different types of discourse and specific communication situations.

\section{References:}

1. Andrieieva V. (2008) Verbalnyie sredstva vyrazheniia kommunikativnogo sabotazha [Verbal means of expressing communicative sabotage]. Vivliophica 
(electronic journal). Retrieved from: https://vivliophica.com/articles/linguistics/654057 (accessed 20 February 2020).

2. Andrieieva V. (2009) Strategii i taktiki kommunikativnogo sabotazha [Communication sabotage strategies and tactics] (PhD Thesis), Kursk.

3. Busel V. T. (2004) Velykyi tlumachnyi slovnyk suchasnoii ukraiinskoii movy [Large explanatory dictionary of the modern Ukrainian language]. Kyiv; Irpin: VTF «Perun». (in Ukrainian)

4. Volkova O. (2009) Pragmalingvisticheskiie osobennosti mezhlichnostnogo obshcheniia v kommunikativnoi situatsii «bytovoi konflikt»: na materiale angliiskogo iazyka [Pragmalinguistic features of interpersonal communication in a communicative situation «everyday conflict»: on the material of the English language] (PhD Thesis), Volhohrad.

5. Kornelius H., Pheir Sh. (1992) Vyigrat mozhet kazhdyi: Kak razreshat konflikty [Everyone Can Win: How to Resolve Conflicts]. Moskow: Stringer. (in Russian)

6. Yarenchuk E. (2013) Kommunikativnyi sabotazh v interaktivnoanaliticheskom diskurse (na materiale tok-shou) [Communicative sabotage in interactive-analytical discourse (based on talk show material)] (PhD Thesis), Kursk. 